\title{
Immunization against recombinant bovine inhibin $\alpha$ subunit causes increased ovulation rates in gilts
}

\author{
R. W. Brown, J. W. Hungerford, P. E. Greenwood, R. J. Bloor†, \\ D. F. Evanst, C. G. Tsonis and R. G. Forage
}

Biotech Australia Pty Ltd, P.O. Box 20, East Roseville, New South Wales 2069, Australia; and † Metro Farms Pty Ltd, Wonga Division, P.O. Box 50, Young, New South Wales 2594, Australia

\begin{abstract}
Summary. Immunization of gilts in a commercial piggery against a fusion protein of the $\alpha$ subunit of bovine inhibin, produced by recombinant DNA methods, resulted in mean ovulation rate increases of $35 \%$ at the oestrus at which, under the piggery's management practices, they would have been mated. Sera from two immunized groups showed mean binding of $6.6 \%$ and $4.9 \%$ when assayed, at 1:800 final dilution, against iodinated bovine inhibin $\left(M_{\mathrm{r}} 31000\right)$. Ovulation rates of immunized gilts were highly correlated with the ability of serum to bind iodinated native inhibin $(r=0.62 ; P<0.001)$, particularly when weight and age were included in the correlation $(r=0.72 ; P=$ 0.001 ), and inhibin binding accounted for $38 \%$ of the total variation in ovulation rate. Immunization caused no deleterious effects on growth rate or onset of oestrus. These results demonstrate the potential for use of such immunization to increase prolificacy in gilts and young sows.
\end{abstract}

Keywords: inhibin; fusion protein; immunization; ovulation rate; gilts

\section{Introduction}

Inhibin is a glycoprotein hormone, consisting of two dissimilar, disulphide-linked, subunits (termed $\alpha$ and $\beta$ ), which inhibits the production and/or secretion of pituitary gonadotrophins, preferentially follicle-stimulating hormone (FSH) (Burger \& Igarashi, 1988).

Previous studies have shown that immunization of sheep against inhibin-enriched fractions of bovine follicular fluid (Henderson et al., 1984; O'Shea et al., 1984; Cummins et al., 1986) and of cattle against inhibin-enriched ovine follicular fluid (Bindon et al., 1988) resulted in increased ovulation rates in both species. Furthermore, O'Shea et al. (1984) demonstrated that the increased ovulation rate in sheep led to an increased number of lambs born.

Forage et al. (1987) used a highly purified fusion protein of the $\alpha$ subunit of bovine inhibin, produced by recombinant DNA methods, to obtain 3-4-fold increases in ovulation rate in sheep, and subsequent trials (Tsonis et al., 1989) have resulted in increased litter sizes from immunized ewes. The hypothesis that increased ovulation rate in ewes immunized against a bovine $\alpha$ subunit fusion protein were due to increases in circulating FSH concentrations was supported by data from Findlay et al. (1989), who demonstrated such increases during the breeding season.

The aim of this study, conducted in a commercial piggery, was to examine the possibility of increasing ovulation rate in gilts by immunization with a fusion protein of the $\alpha$ subunit of bovine inhibin.

\section{Materials and Methods}

Immunogen. The immunogen, which will be referred to as inhibin ba, was a purified fusion protein containing the same bovine inhibin sequence as that used by Forage et al. (1987). Produced in Escherichia coli, it consisted of amino 
acid residues $165-300$ of the $\alpha_{43}$ subunit of bovine inhibin plus a short amino-terminal extension comprising sequences encoded by part of the $E$. coli lac $Z$ gene and by synthetic linker DNA.

Experimental regimen. The trial was conducted at a commercial piggery in New South Wales, Australia, between August and November 1988. The 58 cross-bred gilts, $21-24$ weeks old, $68-85 \mathrm{~kg}$ in weight, were randomly allocated, with respect to age, to 4 treatment groups. Gilts in Groups $1(N=14)$ and $2(N=15)$ were immunized with inhibin $b \alpha$. Those in Group $3(N=15)$ were inoculated with a placebo while Group $4(N=14)$ consisted of gilts that were neither inoculated nor bled.

All gilts were housed in the same location within the piggery and groups were mixed within pens. All gilts were fed ad libitum on a pig grower diet of which the major ingredients were wheat, triticale, lupin, meat meal and oil seed meal. It contained $18.5 \%$ crude protein, $13.8 \mathrm{MJ} / \mathrm{kg}$ digestible energy and the available lysine level was $0.69 \mathrm{~g}$ per $\mathrm{MJ}$ digestible energy. It was medicated with oxytetracycline to control respiratory disease.

All gilts were weighed on Day 0 (Day $0=$ primary injection) and 4 days before slaughter. From Day 43 , all gilts were exposed to boars and tested daily for oestrus. Gilts which exhibited oestrus within a fixed 7-day period were slaughtered at a commercial abattoir 5 days after that period. Testing was conducted for 4 consecutive 7-day periods.

Immunization. Gilts in Groups 1, 2 and 3 were injected intramuscularly in the neck with a 1-ml dose on Days 0 and 28. Those in Groups 1 and 2 received doses consisting of $1 \mathrm{mg}$ inhibin ba formulated in saline-in-oil emulsions. Gilts in Group 1 received a 50:50 (w/w) emulsion in which the oil phase was Montanide 888 (SEPPIC, Paris, France) and Marcol 52 (Esso, Sydney, Australia), mixed in the ratio 1:9. The emulsion received by gilts in Group 2 was 30:70 (w/w) in which the oil phase was Montanide ISA 702 (SEPPIC, Paris, France). Gilts in Group 3 received injections of salinein-oil emulsion only; the oil phase was the same as that delivered to gilts in Group I. Saline was $0.9 \%(w / v) ~ N a C l$ (Steriflex, Kendall McGaw, Victoria, Australia).

Blood sampling. Blood samples $(5-10 \mathrm{ml})$ were collected on Days 0 and 42 via jugular venepuncture. Blood was allowed to clot at ambient temperature followed by storage overnight at $4^{\circ} \mathrm{C}$. Samples were then centrifuged at $1000 \mathrm{~g}$ for $15 \mathrm{~min}$ and serum was decanted. Serum samples were stored at $-20^{\circ} \mathrm{C}$ until assayed. A blood sample was also collected from each animal at slaughter.

Determination of ovulation rate. Ovaries were collected after slaughter and corpora lutea were counted to determine ovulation rate (defined as number of corpora lutea per pair of luteal-phase ovaries collected).

Serology. Serum samples from collections on Days 0,42 and at slaughter were assayed for the ability to bind iodinated native bovine inhibin $(M, 31000)$ in a tracer binding assay previously described (Forage et al., 1987). Briefly, $100 \mu \mathrm{l}$ serum (at 1:800 final dilution) and iodinated bovine inhibin $M_{\mathrm{r}} 31000(100 \mu \mathrm{l}, 10000 \mathrm{c} . \mathrm{p} . \mathrm{m}$.) were incubated in a final volume of $400 \mu \mathrm{l}$ for $17 \mathrm{~h}$ at $20^{\circ} \mathrm{C}$. Rabbit anti-pig serum ( $100 \mu \mathrm{l}$; ICN Immunobiologicals, Lisle, Israel; diluted 1:10) was added and incubated for $30 \mathrm{~min}$ at $20^{\circ} \mathrm{C}$. Polyethylene glycol 6000 (Sigma, St Louis, MO, USA) was added to a final concentration of $6 \%(\mathrm{w} / \mathrm{v})$, tubes were centrifuged at $2000 \mathrm{~g}$ for $45 \mathrm{~min}$ and the pellet counted. Results are presented as percentage c.p.m. bound of total c.p.m. added after correction for non-specific binding determined with normal pig serum.

Statistical analysis. Before analysis, ovulation rate and inhibin binding percentages were transformed (by $\log$ and angular transformations respectively) to approximate normal variates. No other variables required transformation. Parallel parametric and non-parametric tests were used for all analyses. As similar significances were determined by both tests in all instances, only the parametric tests are presented.

All variates (except inhibin binding) were initially examined by one-way analysis of variance. When this resulted in a significant $\mathbf{F}$ value $(P<0.05)$, pairwise comparisons of group means were made using the Newman-Keuls test. The inhibin binding means of the two immunized groups were compared by Student's $t$ test with unequal variance, as were the ovulation rates of the pooled immunized groups versus the pooled control groups. Results are presented as the mean plus $95 \%$ confidence limits or standard error of the mean with the number of observations and the range. Ovulation rate and inhibin binding are presented after back-transformation.

The possibility of a decline in the response to immunization between Day 42 and slaughter was investigated by examining correlations of the length of this period with ovulation rate or with any decline in inhibin binding (as assessed by an absolute difference in inhibin binding of sera collected at Day 42 and at slaughter, or as a proportional change over that period). Inhibin binding at Day 42 and at slaughter were also compared directly by paired $t$ test.

Multiple linear correlation was used to examine the relative influence of the measured variates on ovulation rate. The statistical model for ovulation rate included the effects of age at slaughter, weight at slaughter and inhibin binding.

The regression equation used was:

$$
\hat{Y}=a+b_{1} X_{1}+b_{2} X_{2}+b_{3} X_{3}
$$

where $\hat{Y}=$ predicted $\log$ (ovulation rate), $a=$ intercept; $b_{1}=$ coefficient for age at slaughter; $X_{1}=$ age at slaughter; $\mathrm{b}_{2}=$ coefficient for weight at slaughter; $\mathrm{X}_{2}=$ weight at slaughter; $\mathrm{b}_{3}=$ coefficient for angular inhibin binding and $\mathrm{X}_{3}=$ angular inhibin binding.

To demonstrate the effect of immunization on ovulation rate the coefficients from the above analysis were used to calculate theoretical ovulation rates of immunized animals if: (1) age and weight at slaughter were held constant at the group mean, and (2) inhibin binding were zero. As these calculated ovulation rates were determined by discounting for the effects of measured variates, they will be referred to as discounted ovulation rates. The equations used were: 
(1) Discounting ovulation rate (OR) for age and weight effects:

$$
\log (\text { discounted OR })=\log (\text { observed OR })-b_{t}\left(X_{1}-\bar{X}_{1}\right)-b_{2}\left(X_{2}-\bar{X}_{2}\right)
$$

(2) Discounting ovulation rate (OR) for inhibin binding effect:

$$
\log (\text { discounted } O R)=\log (\text { observed } O R)-b_{3} X_{3}
$$

\section{Results}

More than $80 \%$ of all gilts were observed in oestrus within 21 days of exposure to boars and $90 \%$ were observed in oestrus within 28 days (Table 1). Oestrus was not observed in 4 gilts (2 from Group 2 and 1 each from Groups 1 and 3). However luteal-phase ovaries were recovered from 2 of these gilts ( 1 each from Groups 2 and 3) when they were slaughtered after the last observation of oestrus. Conversely, there were 4 gilts ( 2 from Group 4 and 1 each from Groups 1 and 3) which were observed in oestrus but were not in the luteal phase, as determined by visual examination of the ovaries when slaughtered. Therefore ovulation rate was not determined for a total of 6 gilts.

Table 1. Cumulative numbers of gilts from which luteal-phase ovaries were collected following 4 consecutive 7-day oestrus observation periods

\begin{tabular}{lcccc}
\hline Period & Group 1 & Group 2 & Group 3 & Group 4 \\
\hline 1 & 4 & 4 & 7 & 4 \\
2 & 8 & 9 & 12 & 6 \\
3 & 10 & 13 & 13 & 10 \\
4 & 12 & 14 & 14 & 12 \\
\hline
\end{tabular}

Table 2. Effect of immunization with inhibin b $\alpha$ fusion protein on inhibin binding, ovulation rate and

\begin{tabular}{|c|c|c|c|c|}
\hline & $\begin{array}{c}\text { Group } 1 \\
\text { (immunized) }\end{array}$ & $\begin{array}{c}\text { Group } 2 \\
\text { (immunized) }\end{array}$ & $\begin{array}{l}\text { Group } 3 \\
\text { (placebo) }\end{array}$ & $\begin{array}{c}\text { Group } 4 \\
\text { (not handled) }\end{array}$ \\
\hline $\begin{array}{l}\% \text { Inhibin binding } \dagger \\
\text { (Day-42 sera) }\end{array}$ & $\begin{array}{l}6 \cdot 6^{\mathbf{a}} ; 4 \cdot 4-9 \cdot 1 \\
(14) \quad 0 \cdot 9-13 \cdot 8\end{array}$ & $\begin{array}{l}4 \cdot 0^{\mathrm{a}} ; 2 \cdot 0-6 \cdot 7 \\
(15) \quad 0 \cdot 6-14 \cdot 8\end{array}$ & $\begin{array}{l}<0 \cdot 2^{b} \\
(15)\end{array}$ & N.A. \\
\hline $\begin{array}{l}\% \text { Inhibin binding } \dagger \\
\text { (slaughter sera) }\end{array}$ & $\begin{array}{l}4.9^{\mathrm{a}} ; \quad 3 \cdot 2-6 \cdot 9 \\
(14) \quad 0.6-10 \cdot 1\end{array}$ & $\begin{array}{c}3 \cdot 0^{\text {a. }} ; 1 \cdot 2-5 \cdot 5 \\
(15) \quad 0 \cdot 1-12 \cdot 7\end{array}$ & $\begin{array}{l}<0 \cdot 2^{b} \\
(15)\end{array}$ & N.A. \\
\hline Days to oestrus + & $\begin{array}{l}12 \cdot 3 \pm 2 \cdot 3 \\
(12)\end{array}$ & $\begin{array}{l}11 \cdot 6 \pm 1 \cdot 7 \\
(13)\end{array}$ & $\begin{array}{l}8 \cdot 6 \pm 1 \cdot 4 \\
\text { (13) } \\
3-20\end{array}$ & $\begin{array}{l}13 \cdot 3 \pm 2 \cdot 2 \\
(12) \quad 4-26\end{array}$ \\
\hline Ovulation rate§ & $\begin{array}{l}15 \cdot 9^{\mathrm{a}} ; 12 \cdot 9-19 \cdot 7 \\
(12) 10-33\end{array}$ & $\begin{array}{l}16 \cdot 5^{\mathrm{a}} ; 14 \cdot 3-19 \cdot 0 \\
\text { (14) } 11-27\end{array}$ & $\begin{array}{l}11 \cdot 7^{\mathrm{b}} ; 10 \cdot 7-12 \cdot 8 \\
\text { (14) } 9-16\end{array}$ & $\begin{array}{l}12 \cdot 2^{\mathrm{b}} ; 10 \cdot 9-13 \cdot 7 \\
(12) \quad 9-16\end{array}$ \\
\hline $\begin{array}{l}\text { Age at slaughter } \\
\text { (weeks) }\end{array}$ & $\begin{array}{l}31 \cdot 9 \pm 0 \cdot 3 \\
\text { (14) } 30-33\end{array}$ & $\begin{array}{l}31 \cdot 7 \pm 0 \cdot 4 \\
\text { (15) } 29-34\end{array}$ & $\begin{array}{l}31 \cdot 2 \pm 0 \cdot 4 \\
(15) \quad 29-35\end{array}$ & $\begin{array}{l}31 \cdot 7 \pm 0 \cdot 4 \\
\text { (14) } 30-34\end{array}$ \\
\hline $\begin{array}{l}\text { Weight at } \\
\text { slaughter (kg) }\end{array}$ & $\begin{array}{c}117 \cdot 4 \pm 2 \cdot 2 \\
\text { (14) } 103-131\end{array}$ & $\begin{array}{l}114.9 \pm 1.9 \\
\text { (15) } 96-125\end{array}$ & $\begin{array}{c}114 \cdot 9 \pm 2 \cdot 0 \\
\text { (15) } 102-132\end{array}$ & $\begin{array}{l}116 \cdot 1 \pm 1 \cdot 4 \\
\text { (14) } 107-126\end{array}$ \\
\hline $\begin{array}{l}\text { Growth rate during } \\
\text { trial (g/day) }\end{array}$ & $\begin{array}{c}590 \pm 30 \\
\text { (14) } 429-768\end{array}$ & $\begin{array}{c}562 \pm 30 \\
\text { (15) } 286-732\end{array}$ & $\begin{array}{l}613 \pm 38 \\
\text { (15) } 460-946\end{array}$ & $\begin{array}{c}586 \pm 21 \\
\text { (14) } 446-696\end{array}$ \\
\hline
\end{tabular}
other variates in gilts

Values are mean followed by $95 \%$ confidence limits of the mean or s.e.m., with number of animals or observations in parentheses and the range. N.A. = data not collected. Means in the same row with different superscripts differ at $P<0.01$.

$\dagger \%$ of added tracer precipitated in assay by serum at $1: 800$ final dilution.

†nterval from Day 43 to observed oestrus.

$\$$ Corpora lutea counted per pair of luteal-phase ovaries collected. 

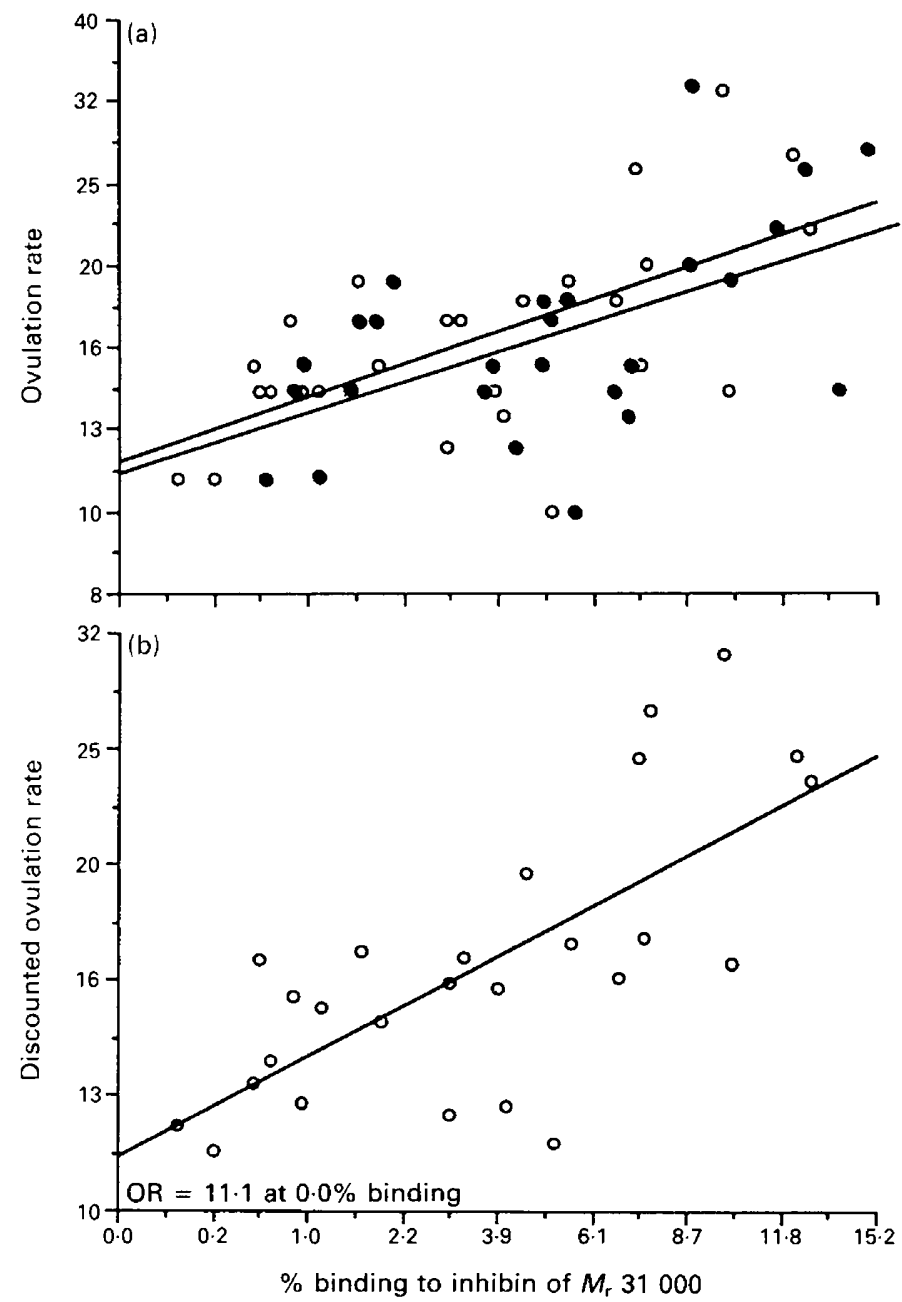

Fig. 1. Effect on ovulation rate (OR) of ability of serum to bind native inhibin in gilts immunized against inhibin ba. (a) Regression of ovulation rate to inhibin binding at Day 42 [log $\mathrm{OR}=0.719(\arcsin (\operatorname{sqrt}(\operatorname{bind} \%)))+\log (11.2), r=0.56 ; P<0.004$ (bottom line, $)]$ or at slaughter $[\log \mathrm{OR}=0.780(\arcsin (\operatorname{sqrt}(\operatorname{bind} \%)))+\log (11.5), r=0.62 ; P<0.001$ (top line, $O)$ ]. (b) Relationship of $O R$, discounted for effects of weight and age (by adjusting variates to group means of $116.1 \mathrm{~kg}$ and 31.8 weeks respectively), to inhibin binding at slaughter [log $\mathrm{OR}=0.872(\arcsin (\operatorname{sqrt}($ bind $\%)))+0.034($ age, weeks $)+0.005($ wt, $\mathrm{kg})-0.655, r=0.72$; $P<0.001]$.

Table 2 presents comparisons between group means of observed variates. Immunization, demonstrated by the ability of serum collected on Day 42 and at slaughter to bind iodinated native inhibin, was associated with significant increases in ovulation rate $(P<0 \cdot 01)$. Serum samples collected on Day 0 did not bind the native inhibin tracer (data not shown). No effect was observed on onset of oestrus after exposure to boars or on growth rate during the trial.

The mean inhibin binding and ovulation rate for the group did not differ significantly between each of the treatment groups ( 1 and 2 ) or between each of the control groups ( 3 and 4$)$. Therefore, for further analysis of results, Groups 1 and 2 were pooled to form an immunized group and Groups 3 and 4 pooled as a control group. There was a significant $(P<0.001)$ group mean increase 
Table 3. Analysis (multiple linear regression) of relative contributions to variation in ovulation rate

\begin{tabular}{|c|c|c|c|c|c|}
\hline Serum & Term & Coefficient & s.e. & $\begin{array}{l}\text { Contribution } \\
\text { to variation* }\end{array}$ & Significance \\
\hline Day 43 & $\begin{array}{l}\text { Intercept } \\
\text { Inhibin binding } \\
\text { Age at slaughter (weeks) } \\
\text { Weight at slaughter }(\mathrm{kg})\end{array}$ & $\begin{array}{r}-0.612 \\
0.812 \\
0.027 \\
0.007\end{array}$ & $\begin{array}{l}0.665 \\
0.202 \\
0.016 \\
0.003\end{array}$ & $\begin{array}{r}- \\
31 \% \\
6 \% \\
11 \%\end{array}$ & $\begin{array}{l}P>0.1 \\
P<0.001 \\
P<0.097 \\
P<0.027\end{array}$ \\
\hline \multicolumn{6}{|c|}{$\begin{array}{l}\text { Standard errror of regression: } 0.095 \\
\mathrm{R}^{2}=0.479 \\
\text { Significance: } P<0.003\end{array}$} \\
\hline At slaughter & $\begin{array}{l}\text { Intercept } \\
\text { Inhibin binding } \\
\text { Age at slaughter (weeks) } \\
\text { Weight at slaughter }(\mathrm{kg})\end{array}$ & $\begin{array}{r}-0.655 \\
0.872 \\
0.034 \\
0.005\end{array}$ & $\begin{array}{l}0.621 \\
0.187 \\
0.015 \\
0.003\end{array}$ & $\begin{array}{r}- \\
38 \% \\
9 \% \\
7 \%\end{array}$ & $\begin{array}{l}P>0.1 \\
P<0.001 \\
P<0.031 \\
P<0.062\end{array}$ \\
\hline \multicolumn{6}{|c|}{$\begin{array}{l}\text { Standard errror of regression: } 0.089 \\
\mathrm{R}^{2}=0.545 \\
\text { Significance: } P<0.001\end{array}$} \\
\hline
\end{tabular}

* Contribution to variation is the percentage of total variation accounted for by that variable, assessed by its contribution to $\mathrm{R}^{2}$.

in ovulation rate of $\mathbf{4} \cdot 2$ corpora lutea associated with immunization against inhibin ba. The $95 \%$ confidence limits of the increase were $2 \cdot 3-6 \cdot 5$.

Because gilts were slaughtered at different intervals after inoculation, the possibility of a decline in the effect of immunization was considered. Correlation of number of days between Day 42 and slaughter with ovulation rate or with changes in serum binding percentages were not significant $(P>0 \cdot 1)$. The mean immunized binding at Day 42 was, however, significantly higher than that at slaughter $(P<0.02)$ (Table 1$)$.

The relative influences on ovulation rate of all measured parameters were investigated. No significant correlation was established in the controls. In the immunized gilts (Table 3), inhibin binding was highly correlated with ovulation rate $(P<0.005)$ (Fig. la). The ability of samples of serum collected at slaughter to bind inhibin was slightly more highly correlated with ovulation rate than was that of samples collected on Day $42(r=0.62$ vs 0.56$)$ but this difference was not significant. Age and weight at slaughter were significantly correlated, in immunized gilts, with ovulation rate only when binding was included in the regression (Table 3; Fig. 1b). Neither the interval between Day 43 and the onset of oestrus nor growth rate was significantly correlated with ovulation rate $(P>0 \cdot 1)$.

The coefficients from the regression of ovulation rate with serum inhibin binding, age and weight at slaughter (Table 3) were used to determine (1) the effect of immunization on ovulation rate when age at slaughter and weight at slaughter were held constant at the group mean of 31.8 weeks and $116.1 \mathrm{~kg}$ (Fig. 1 b) and (2) the ovulation rate if inhibin binding were zero. The means of age and weight discounted ovulation rate (1) and observed ovulation rate did not differ significantly (16.30 vs $16 \cdot 20, P>0 \cdot 1)$, confirming that there was minimal contribution to the observed mean ovulation rate from the ranges of weight and age. Discounting ovulation rate for inhibin binding effects (2) yielded a mean ovulation rate in immunized gilts of $11 \cdot 1$ which is not significantly different from the mean for the pooled controls $(12 \cdot 0)(P>0 \cdot 1)$.

\section{Discussion}

Immunization of gilts against inhibin ba led to increases in mean ovulation rate of $35 \%$ and these increases were highly correlated with the ability of serum to bind iodinated native inhibin 
$M_{\mathrm{r}} 31000$. These findings extend qualitatively to the pig what has been reported for sheep (Tsonis et al., 1989).

Immunization of sheep with an inhibin ba fusion protein (Forage et al., 1987; Tsonis et al., 1989) demonstrated the ability of the unglycosylated subunit produced in a prokaryote, to elicit antibodies capable of recognizing iodinated native inhibin. We have used this property of the immunogen to study the serological response to immunization in the gilt. The iodinated native molecule used was bovine inhibin $M_{\mathrm{r}} 31000$ because of its availability to us for routine use. Sequence analysis of cDNAs encoding bovine and porcine inhibin demonstrates $>90 \%$ amino acid sequence homology between the two species (Mason et al., 1985; Forage et al., 1986) and preliminary binding assays in which sera were assayed against bovine and porcine inhibins indicated similar patterns of binding of the two tracers (data not shown). Presumably the fusion protein presents a variety of epitopes, some of which elicit antibodies which will also bind to the native cattle and pig hormones.

Examination in immunized gilts of the relative influences on ovulation rate of the variates age, weight and inhibin binding demonstrated that the last of these accounted for $38 \%$ of the total variation in ovulation rate (Table 3), and discounting for the effects of binding yielded ovulation rates which were not significantly different from unimmunized animals. Therefore we believe that increases in ovulation rate were achieved via neutralization of endogenous pig inhibin in vivo, presumably leading to perturbation of FSH secretion. Findlay et al. (1989) and Mizumachi et al. (1990) demonstrated increased FSH secretion in ewes immunized against recombinant $\alpha$ subunit, while Hasegawa et al. (1988) have suggested that FSH secretion during the oestrous cycle of the pig is mainly controlled by inhibin.

This study was conducted under a regimen which was, as far as possible, consistent with the piggery's standard practices for management of gilts selected to join the breeding herd, i.e. selection at approximately 22 weeks, exposure to boars from 28 weeks and mating at an average of approximately 31 weeks. The increases in ovulation rate therefore were achieved at the oestrus at which trial gilts would have been mated had they been destined for the breeding herd. The duration of the effect of immunization was not determined but there was no evidence of a decline in the effect on ovulation rate over the period between Days 42 and 70 , during which $90 \%$ of the gilts could have been mated.

The extent to which increased ovulation rate in gilts would affect litter size is currently under investigation. Litter size in pigs is determined by the number of ova shed and the proportion of those ova which are delivered as live piglets and these determinants are not themselves independent factors (Wrathall, 1971).

Various studies have shown that prenatal survival (expressed as the proportion of total ova resulting in live fetuses or piglets) decreases with increasing ovulation rate (Blichfeldt \& Almlid, 1982; King \& Williams, 1984; Johnson et al., 1985). One of the most studied postulated determinants of prenatal survival has been uterine capacity (Knight et al., 1977; Dziuk, 1985; Christenson et al., 1987; Wu et al., 1987) and data from unilaterally hysterectomized-ovariectomized gilts and from slaughtered pregnant sows have confirmed that uterine space is limiting on litter size when a large number of fetuses is present. However, such studies have also indicated that, over the range of ovulation rates of up to at least 18 corpora lutea, litter size is still positively related to ovulation rate. King \& Williams (1984), in a study of first-litter sows, demonstrated a positive correlation between litter size and ovulation rate up to at least 23 corpora lutea, with each extra ovum between 8 and 23 resulting in $0 \cdot 3$ live piglets at farrowing.

The findings of the above and present studies indicate that immunization against inhibin b $\alpha$ fusion protein could be used to increase prolificacy in gilts and young sows.

We thank Dr D. M. Robertson and A. O'Connor from the Department of Anatomy, Monash University, for the provision of iodinated bovine inhibin; Dr K. Miyamoto, Department of Obstetrics and Gynecology, Gunma University School of Medicine, Japan, for the gift of porcine 
inhibin tracer; Professor H. G. Burger, who made the porcine inhibin tracer available to us; Dr J. K. Findlay, Prince Henry's Hospital, Melbourne, for useful discussion; and Mrs R. Smith for preparation of this manuscript.

\section{References}

Bindon, B.M., O’Shea, T., Miyamoto, K., Hillard, M.A., Piper, L.R., Nethery, R.D. \& Uphill, G. (1988) Superovulation in pubertal heifers immunized against ovine inhibin purified by monoclonal antibody affinity chromatography. Proc. Aust. Soc. Reprod. Biol. 20, Abstr. 28.

Blichfeldt, T. \& Almlid, T. (1982) The relationship between ovulation rate and embryonic survival in gilts. Theriogenology 18, 615-620.

Burger, H.G. \& Igarashi, M. (1988) Inhibin: definition and nomenclature, including related substances. Endocrinology 122, 1701-1702.

Christenson, R.K., Leymaster, K.A. \& Young, L.D. (1987) Justification of unilateral hysterectomy-ovariectomy as a model to evaluate uterine capacity in swine. $J$. Anim. Sci. 65, 738-744.

Cummins, L.J., O'Shea, T., Al-Obaidi, S.A.R., Bindon, B.M. \& Findlay, J.K. (1986) Increase in ovulation rate after immunization of Merino ewes with a fraction of bovine follicular fluid containing inhibin activity. J. Reprod. Fert. 77, 365-372.

Dziuk, P.J. (1985) Effect of migration, distribution and spacing of pig embryos on pregnancy and fetal survival. J. Reprod. Fert., Suppl. 33, 57-63.

Findlay, J.K., Doughton, B., Robertson, D.M. \& Forage, R.G. (1989) Effects of immunization against recombinant bovine inhibin $\alpha$ subunit on circulating concentrations of gonadotrophins in ewes. $J$. Endocr. 120, $59-65$.

Forage, R.G., Ring, J.M., Brown, R.W., McInerney, B.V., Cobon, G.S., Gregson, R.P., Robertson, D.M., Morgan, F.J., Hearn, M.T.W., Findlay, J.K., Wettenhall, R.E.H., Burger, H.G. \& de Kretser, D.M. (1986) Cloning and sequence analysis of cDNA species coding for the two subunits of inhibin from bovine follicular fluid. Proc. natn. Acad. Sci. USA 83, 3091-3095.

Forage, R.G., Brown, R.W., Oliver, K.J., Atrache, B.T., Devine, P.L., Hudson, G.C., Goss, N.H., Bertram, K.C., Tolstoshev, P., Robertson, D.M., de Kretser, D.M., Doughton, B., Burger, H.G. \& Findlay, J.K. (1987) Immunization against an inhibin subunit produced by recombinant DNA techniques results in increased ovulation rate in sheep. $J$. Endocr. 114, RI-R4

Hasegawa, Y., Miyamoto, K., Iwamura, S. \& Igarashi, M. (1988) Changes in serum concentration of inhibin in cyclic pigs. J. Endocr. 118, 211-219.

Henderson, K.M., Franchimont, P., Lecomte-Yerna, M.J., Hudson, N. \& Ball, K. (1984) Increase in ovulation rate after active immunization of sheep with inhibin partially purified from bovine follicular fluid. J. Endocr. 102, 305-309.
Johnson, R.K., Zimmerman, D.R., Lamberson, W.R. \& Sasaki, S. (1985) Influencing prolificacy of sows by selection for physiological factors. J. Reprod. Fert., Suppl. 33, $139-149$.

King, R.H. \& Williams, I.H. (1984) The influence of ovulation rate on subsequent litter size in sows. Theriogenology 21, 677-680.

Knight, J.W., Bazer, F.W., Thatcher, W.W., Franke, D.E. \& Wallace, H.D. (1977) Conceptus development in intact and unilaterally hysterectomizedovariectomized gilts: interrelations among hormonal status, placental development, fetal fluids and fetal growth. J. Anim. Sci. 44,620-637.

Mason, A.J., Hayflick, J.S., Ling, N., Esch, F., Ueno, N., Ying, S-Y., Guillemin, R., Niall, H. \& Seeburg, P.H. (1985) Complementary DNA sequences of ovarian follicular fluid inhibin show precursor structure and homology with transforming growth factor $\beta$. Nature, Lond. 318, 659-663.

Mizumachi, M., Voglmayr, J.K, Washington, D.W., Chen, C.L.-C. \& Bardin, C.W. (1990) Superovulation of ewes immunized against the human recombinant inhibin $\alpha$ subunit associated with increased preand post-ovulatory FSH level. Endocrinology 126, 1058-1063.

O'Shea, T., Al-Obaidi, S.A.R. \& Hillard, M.A. (1984) Increased ovulation rate in merino ewes and advancement of puberty in merino lambs immunized with a preparation enriched in inhibin. In Reproduction in Sheep, pp. 335-337. Eds D. R. Lindsay \& D. T. Pearce. Australian Academy of Science, Canberra.

Tsonis, C.G., Borchers, C.E., Hungerford, J., Tierney, L., Pearson, M., Brown, R., Braid, G., Doughton, B., Findlay, J., Greenwood, P.E. \& Forage, R.G. (1989) Effects on ovulation and lambing rates after immunizing sheep with recombinant inhibin $\alpha$ subunit. Proc. 8th Australian Biotech. Conf., Sydney, pp. 444-447.

Wrathall, A.E. (1971) Ovulation rate and its influence on prenatal survival and litter size in pigs. In Prenatal Survival in Pigs, pp. 1-94. Commonwealth Agricultural Bureax, Farnham Royal.

Wu, M.C., Hentzel, M.D. \& Dziuk, P.J. (1987) Relationships between uterine length and number of fetuses and prenatal mortality in pigs. J. Anim. Sci. 65, 762-770. 